\title{
原子間力顕微鏡チップー表面間相互作用の 原子直視型透過電子顕微鏡観察*
}

\author{
木 塚 徳 志*1
}

（受理1997年11月19日，掲載決定1998年 1月10日）

\section{Direct Atomic TEM Observation of AFM Tip-Surface Interaction Tokushi KIZUKA}

\author{
(Research Center for Advanced Waste and Emission Management, Negoya University, \\ Department of Applied Physics, Faculty of Engineering, Nagoya University, \\ Furo-cho, Chikusa-ku, Nagoya, 464-8603, Japan
}

(Received November 19, 1997, Accepted January 10, 1998)

\begin{abstract}
Atomic processes of mechanical interaction between a tip of atomic force microscopy (AFM) and surfaces were directly observed by time-resolved high-resolution transmission electron microscopy at spatial resolution of $0.2 \mathrm{~nm}$ and time resolution of $1 / 60 \mathrm{~s}$.

A piezo-driving specimen holder of transmission electron microscopy (TEM) was develoved for the observation of AFM tip-surface interaction. Nanometer-sized tips of gold were allowed to be approached, contacted, bonded, deformed and fractured inside a $200 \mathrm{kV}$ TEM using the specimen holder. Atomic scale contact or non-contact type surface-scanning corresponding to AFM operation was performed using the gold tip. No structural modulation was observed during the non-contact type scanning. On the other hand, the crystallographic boundary formed between the tip and surface during the contact-type scanning. It was found that stick-slip motion appears due to the boundary formation. A few atomic layers near the surfaces and the boundaries were responsible for the contact-type scanning. The surface structure changed after the scanning.
\end{abstract}

\section{1. はじめに}

走査プローブ顕微鏡を用いると，真空に密接に関わる 表面の構造を原子レベルで解析することがでさる．この 走査プローブ顕微鏡では, 表面と探針間境界のトンネル 電流や機械的相互作用によって観察像を再構成する．信 頼ある解析をするためにはこのよらな近接物理現象の的 確な評価が必要である. 著者は $0.2 \mathrm{~nm}$ の空間分解能と $1 / 60$ 秒の時間分解能を併せるつ時間分解型透過電子顕微 鏡法とピェゾ素子駆動方式の特殊試料ホルダーを開発

* 平成 9 年 11 月 7 日 第38回真空に関する連合講演会で特別講演

*1 名大難処理研, 名大工 (464-8603 名古屋市千種区不老町)
し, 近接物理現象に和ける構造ダイナミクスの原子過程 をその場で直接観察することに成功した.

この速報では, $2 つ の$ 結晶チップ表面間に生じる接 近, 接触, 接合, 変形, 破断などのダイナミクスの原子 直視型観察について報告する.

\section{2. 実験方法}

電子影微鏡内で 2 つ物質間に機械的相互作用を生じ させたり，これらを組み合わせた表面走查，原子操作を 行らために，著者はピェゾ素子駆動方式による電子顕微 鏡特殊試料ホルダーを開発した (Fig. 1) ${ }^{1,2)}$. 可動側試 料支持台は微小変位用の円筒状ピエゾ素子と粗動変位用 のモーターに接続している.モーターによって可動側試 

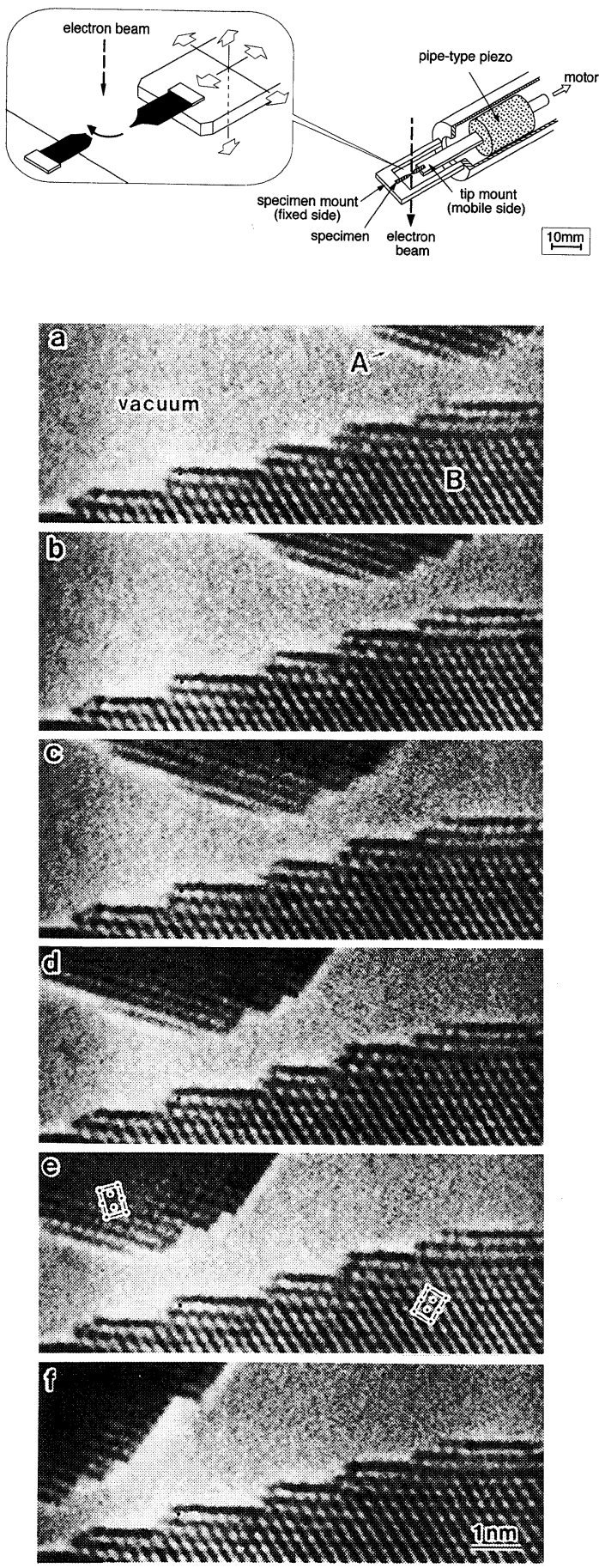

Fig. 2 Direct atomistic observation of non-contact type scanning on a gold surface (B) by a gold tip (A). The distance betwseen the two tips is kept 1.0 nm. Frames show the unit cells of gold projected along [110] direction. Time is $0.0 \mathrm{~s}$ (a), $0.9 \mathrm{~s}$ (b), $1.8 \mathrm{~s}(\mathrm{c}), 2.6 \mathrm{~s}(\mathrm{~d}), 3.2 \mathrm{~s}$ (e) and $4.3 \mathrm{~s}(\mathrm{f})$.
Fig. 1 Illustration of a piezo-driving specimen holder of a high-resolution transmission electron microscope for atomic scale surface-scanning.
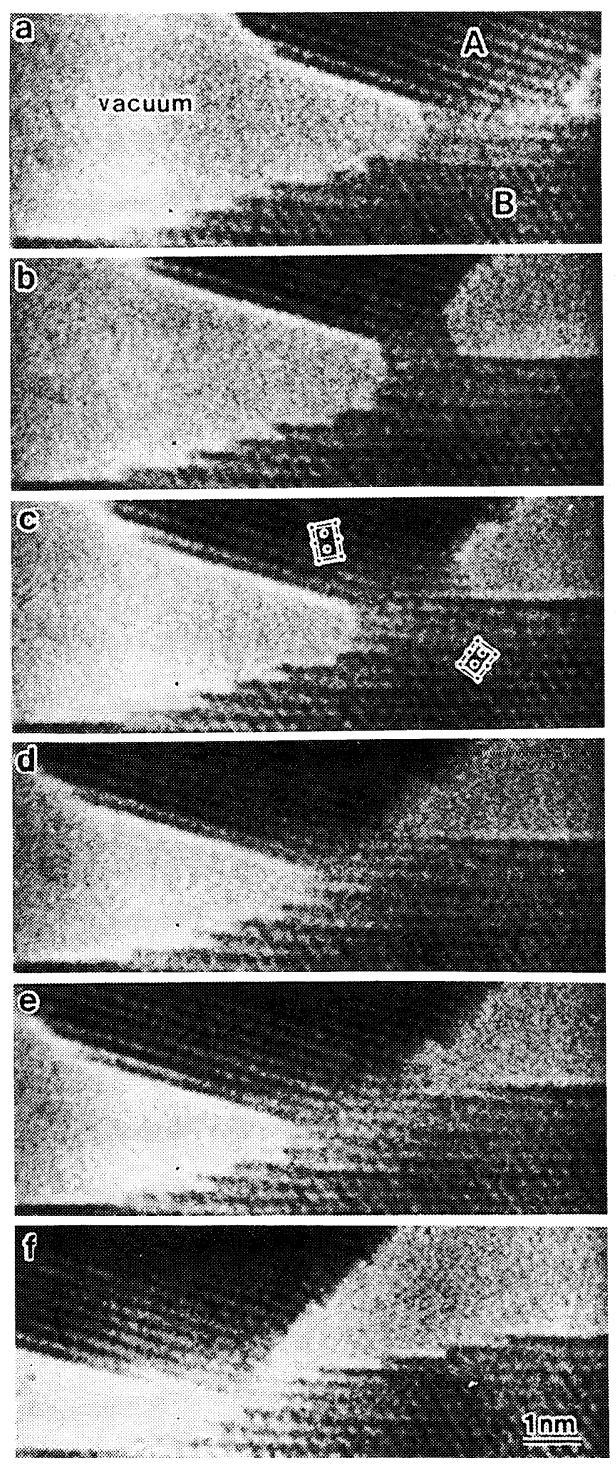

Fig. 3 Direct atomistic observation of contact type scanning on a gold surface (B) by a gold tip (A). The two tips bond by a boundary of a few atomic columns width. Frames show the unit cells of gold projected along [110] direction. Time is $0.0 \mathrm{~s}$ (a), $2.2 \mathrm{~s}(\mathrm{~b}), 3.7 \mathrm{~s}(\mathrm{c}), 6.7 \mathrm{~s}(\mathrm{~d}), 10.4 \mathrm{~s}(\mathrm{e})$ and $12.6 \mathrm{~s}$ (f). 
料を $\mathrm{x}$ 方向に最大 $\pm 1 \mathrm{~mm}$ 変位できる. $\mathrm{x}$ 方向の微小変 位をピェゾ素子のこの方向に沿った均一な伸縮によって 調節でさる. ピェゾ素子駆動による $\mathrm{x}$ 方向の最大変位量 と最小変位量はそれぞれ $1.2 \mathrm{~mm}, 0.16 \mathrm{~nm}$ である. $\mathrm{y}$ お よび $\mathrm{z}$ 方向の微小变位はピエゾ素子の片側の伸縮によっ て調節される. y 方向の最大変位量と最小変位量はそれ ぞれ $11.4 \mathrm{~mm}, 0.22 \mathrm{~nm}$ である. 電子線入射方向と平行 なz方向の最大変位量と最小変位量はy方向のそれと同様 である．ピエゾ素子によって+100 $\mathrm{nm}$ 変位させた後の 履歴による移動量は $\mathrm{x}, \mathrm{y}$ 方向それぞれ $1.3 \mathrm{~nm}, 2.5 \mathrm{~nm}$ である。

本研究では, 99.999\%の多結晶の金線を試料として用 いた. 直径は $0.1 \mathrm{~mm}$, 長さは $5 \mathrm{~mm}$ である. 2 つの線の 先端をアルゴンイオン照射によって研磨して，それらが 向かい合らょらに試料ホルダーの可動側, および固定側 試料支持台に固定した. この試料ホルダーを $200 \mathrm{kV} の$ 高分解能透過電子顕微鏡（日本電子社：JEM-2010）に 入れた. ピェゾ素子を駆動して, 可動側支持端を xyzの 3 方向に変位させ, 接触する位置を $0.01 \mathrm{~nm}$ 以下の間隔 で調整する．次に先端同士を接近，接触，または接合さ せ, 非接触型, 接触型の表面走查を行った. この過程を その場で高分解能観察し, SIT 型テレビカメラとビデオ テープ装置を用いて記録した，観察時の空間分解能は $0.2 \mathrm{~nm}$, 時間分解能は画像の 1 単位視野に対応する $1 /$ 60秒である.

\section{2. 結果}

Fig. 2 は非接触型の表面走査の過程を連続的に観察し
た高分解能観察像である. 固定側試料先端 (B) と可動側 試料先端(A)に現れている $\{111\}$ 格子縞から，それぞれ の表面原子配列を解析することがでさる.ここでは $2 つ$ の試料先端間の距離を約 $1 \mathrm{~nm}$ 程離している. 走査中に 可動側試料先端はなめらかに変位する.この走査前後で は表面原子配列の変化はみられない.

これに対し, Fig. 3 は 2 つの試料先端を接触させなが ら, 表面走査したときの高分解能観察像である.これは 接触型原子間力影徽鏡での表面走査に対応する. 2 つ 試料先端の境界には数原子幅のネックが形成されて拉 り，走査とともにこのネックは移動する．Fig. 2 の場合 と異なり, 可動側試料は不均一な動さ（Stick-slip motion）を示す．これはネック形成により，動的な摩擦が 生じているためである. 走査の前後では表面近傍の数原 子層の原子配列が変化していることがこの断面観察より 明らかである. 孤立した数原子幅のテラスはこの走査に より消隇する.

このよらな形で原子スケールの摩擦の研究や, 原子操 作扣よび走査プローブ顕微鏡の基礎研究に本直接観察法 を利用することができる.

\section{[文献〕}

1) T. Kizuka, K Yamada, S. Deguchi, M. Naruse and N. Tanaka: Phys. Rev., B55 (1997) R7398.

2) T. Kizuka, K Yamada, S. Deguchi, M. Naruse and N. Tanaka: J. Electron Microscopy, 46 (1997) 151. 